Research.

\title{
Earning management practices in Islamic banking in Indonesia
}

\author{
Siti Chanifah ${ }^{1^{\star}}$, Hamdani ${ }^{2}$, and Mutiara Wiedyaningtias ${ }^{3}$ \\ 1,2,3 Department of Accounting, Muhammadiyah Tangerang University, Jakarta, Indonesia \\ 1najahansiti57@yahoo.com, ${ }^{2}$ hamdani_82m@yahoo.com, ${ }^{3}$ mutiarawiedyaningtias@gmail.com \\ * Corresponding author
}

Received: February 15, 2020; Accepted: April 27, 2020; Published: June 30, 2020.

To cite this article: Chanifah, S., Hamdani, and Wiedyaningtias, M. (2020). Earning management practices in Islamic banking in Indonesia. The Accounting Journal of BINANIAGA. 5 (1): 09-18. doi: 10.33062/ajb.v5i01.364

\begin{abstract}
This study discusses to study earnings management practices in Islamic banking which are listed on the Indonesia Stock Exchange for the 2012-2016 period. Research using quantitative descriptive. The population in this study is the Islamic banking sector in Indonesia. Research samples at 11 Sharia Commercial Banks (BUS) reported on the Indonesia Stock Exchange. The data analysis technique used is descriptive analysis, with earnings management calculations using the Friedlan Model. The variable analyzed is earnings management using discretionary accruals. The results of this study show how earnings management practices occur in 11 Islamic banks in Indonesia. Value-added positive discretionary accruals indicate that there are earnings management practices by increasing earnings or increasing revenue and negative value discretionary accruals values indicate how earnings management practices by decreasing earnings or income decreases.
\end{abstract}

Keywords: Earnings Management, Discretionary Accruals, Islamic Banking

\section{BACKGROUND}

The interest of investors and shareholders (stakeholders) who only focus on the profit information provided by the company in the profit / loss statement will be an incentive for managers of a corporation to practice earnings management. Earnings management can be categorized as an act of fraud (fraud). This is based on the consideration that in the practice of earnings management, management displays financial reports that are tailored to their desires. Various cases of fraud in Indonesia, one of which is the Toshiba corporate financial scandal by accounting fraud worth 1.22 billion US dollars in the last 3 years on its financial reporting (https://integrity-indonesia.com. 2017).

The case that occurred in the banking sector, occurred in Bank Syariah Bukopin in the consolidated report for the 2016 fiscal year which was reported to the Indonesia Stock Exchange (BEI) as of March 2018 there was a difference with the previous financial statements. In this case, it has not been determined whether Bukopin is carrying out data manipulation activities in connection with the actions to be taken by Bukopin's bank with clarification to be given to the OJK and IDX in relation to the irregularities in the financial statements (kontan.co.id, 2018).

Islamic banks are financial institutions that operationally refer to Islamic principles and values. It is not allowed to manipulate or manipulate profits in preparing financial statements. According to Padmantyo (2010: 54), the manifestation of management's responsibility is not only to those who are interested, but rather is responsible to Allah SWT and the universe. Parties with an interest in Islamic banking financial statements, such as the owner of the funds, those who use or receive the distribution of funds, zakat payers, 
shareholders, supervisory authorities, Bank Indonesia, the government, the Deposit Insurance Corporation, and the public.

This research was conducted to see earnings management practices that occur in Islamic banking. The reason for choosing Islamic banking as an object of research is because Islamic banking is a financial institution that adheres to an Islamic economic system that does not allow an interesting system in transactions. Although theoretically, Islamic banking operates a profit-sharing system, in practice it is possible that Islamic banks carry out earnings management policies, namely smoothening of profits and lost deposit sharing returns in an intensive manner in the form of returns to IAHs (investment account holders) that equal market values with benchmarks or benchmark. In addition, this policy is also often carried out by bank management forming reserve funds taken from the portion of the location of the IAH from the previous accounting period. So that this situation will potentially increase the potential for asymmetric information for Islamic banking stakeholders (Padmantyo, 2010).

Padmantyo (2010) in his research shows that earnings management practices occur in the financial statements of Bank Syariah Mandiri and Bank Muamalat Indonesia. This is in line with research by Faradila and Cahyati (2013), which states that earnings management occurs in Islamic banking in Indonesia. The practice of earnings management in sharia-based financial institutions until now has become a polemic that still cannot be deciphered. Sharia banking should act honestly and openly in financial statements that are presented as material for public consideration in selecting banks based on Islamic principles. In reality, there are still earnings management practices in financial reporting, especially in Islamic banks. This is very contradictory to its role, as a bank that implements an Islamic system in its operations.

This research on earnings management is interesting to study because Islamic banks should apply honesty in the financial statements presented and until now it is a question whether there are still Islamic banks that perform earnings management actions as management decisions. Therefore, the authors chose to make an analysis of earnings management in the Islamic banking sector. The similarity of this research with previous research lies in the object, while the difference lies in the period of research and the use of measuring instruments on the proxy of earnings management. Formulation of the problem raised, Are there earnings management in the 2012 Islamic banking financial statements until 2016?

\section{LITERATURE REVIEW AND HYPOTHESIS DEVELOPMENT}

\section{Agency Theory}

The assumption of agency theory is that each individual is solely motivated by his own interests, causing a conflict of interest between the principal and agent (Anthony \& Govindarajan, 1995). Principals are motivated to enter into contracts to prosper themselves through increasing profitability, while agents are motivated to maximize the fulfillment of their economic and psychological needs. Agency problems occur because of the separation of ownership and management of the company (Cruthley and Hansen, 1989). Problems that occur between owners and managers cause equity agency costs (equity agency cost). According to Jensen and Meckling (1976), there are three types of agency costs, namely monitoring costs by the principal, bonding costs by agents and residual loss. Monitoring costs are incurred by the principal to limit agent activity. Boding cost is a cost issued by the owner-manager to guarantee to shareholders (equity holders) that managers will limit activities that will lead to non-cash benefits for managers (non-pecuniary benefits) (Jesen \& Meckling, 1976). While a residual loss is a prosperity in the value of money that falls as a result of these different interests (Jesen and Meckling, 1976). This decline in prosperity occurs because of the difference between agent decisions and decisions that will maximize principal prosperity.

Siti Chanifah, Hamdani, and Mutiara Wiedyaningtias. Earning management practices in Islamic banking in Indonesia 


\section{Definition of Earning Management}

According to Scott (2009: 403), earnings management is the manager's decision to choose certain accounting policies that are considered to be able to achieve the desired goals, either to increase profits or reduce reported losses. Earnings management is also interpreted as an effort by company managers to intervene or influence the information in financial statements with the aim of fooling stakeholders who want to know the performance and condition of the company (Sulistyanto, 2014). While Merchant (1989), defines earnings management as an action taken by company management to influence reported earnings and can provide information about economic benefits (economic disadvantage) that are not actually experienced by the company. In the long run, these actions can be detrimental to the company.

Davidson, Stickney, and Weil (1987), explain earnings management as a process of taking certain deliberate steps within the limits of general accounting receipts to produce the desired level of reported earnings. The same definition is explained by Healy and Wahlen (1999), where earnings management arises when managers use certain decisions in financial reporting and change transactions to change financial statements to mislead stakeholders who want to know the economic performance obtained by the company.

From the description above, it can be concluded that earnings management is a managerial activity that can influence and intervene in the company's financial statements so that managers can achieve the desired goals such as increasing or reducing the numbers contained in the financial statements while it is still within the scope of accounting. According to Scoot (2006), the motivation of management to practice earnings management in the company's financial statements, namely: bonus purposes (bonus motivation), debt covenant (debt contract), and political motivation, taxation motivation.

\section{Discretionary Accruals and Nondiscretionary Accruals}

Discretionary accruals are an accrual component of the manager's engineering by utilizing freedom and flexibility in estimating and using accounting standards (Sulityanto, 2014: 164). There are several methods that can be used by company managers to engineer the size of the discretionary accrual in accordance with the objectives to be achieved, for example, the freedom to determine estimates and choose the method of depreciation of fixed assets, determine the estimated percentage of the number of uncollectible receivables, choose the method of determining the amount of inventory and so on. Non-discretionary accruals are accrual components that are obtained naturally from the basis of recording accruals by following generally accepted accounting standards, for example, the depreciation method and determining the inventory chosen must follow the methods recognized in accounting principles (Sri Sulistyanto, 2014: 164).

\section{Earning Management Practices in Islamic Banking}

Earnings management is an effort made by managers in a particular company or institution in the hope that it can increase or decrease the results of financial statements to increase the value of the company. But in relation to Islamic banking, earnings management should not be carried out in sharia-based business activities, because it is not in accordance with the application of the system that should be run by Islamic banks. The reality is that financial institutions, especially Islamic banks, in general, are known to have carried out earnings management in their operational activities. Indicated earnings management is carried out with positive and negative Discretionary Accruals for 2 years on Islamic bank financial statements (Faradila and Cahyati, 2013). Thus the arguments above can be used in formulating a hypothesis as follows:

$\mathrm{H} 1=\mathrm{It}$ is suspected that there is earnings management in Islamic banking on the Indonesia Stock Exchange.

Siti Chanifah, Hamdani, and Mutiara Wiedyaningtias. Earning management practices in Islamic banking in Indonesia 


\section{RESEARCH METHODS}

The research uses a quantitative descriptive approach. The population in this study is the Islamic banking sector in Indonesia. Research samples at 11 Islamic Commercial Banks (BUS) listed on the Indonesia Stock Exchange. The data analysis technique used is descriptive analysis, with earnings management calculations using the Friedlan Model. The variable analyzed is earnings management using the discretionary accruals approach as the preferred instrument for managing the reported numbers because the costs are relatively low and nature is not easily observed. Earnings management is measured by discretionary accrual (DAC) which is calculated by calculating the difference in total accrual (TACC) and non-discretionary accrual (NDAC). To calculate the DAC, Friedlan's model (Hendra, Yie, 2005) is used to make adjustments to the calculation of total accruals, which has the assumption that a constant proportion between total accruals and sales is in successive periods. Therefore, the total amount of accruals attached to management discretion is the difference between total accruals in the period under test and standardization with sales in the period under test and total accruals in the base period standardized with sales in the base period. Formally the calculation is as follows:

1. Calculating Total Accruals (TAC) for period $t$ can be expressed by the following equation:

$\mathrm{TACT}=$ NIT - CFOT

Where:

TACT $=$ Total accruals in T period

NIT = Operating profit for T period.

CFOT = Cash flow from operating activities at the end of the year $\mathrm{T}$.

2. Measuring Discretionary Accruals (DAC) using the formula:

$$
\mathrm{DACPT}=\left(\frac{\mathrm{TACPT}}{\text { SalesPT }}\right)-\left(\frac{\mathrm{TACPD}}{\text { SalesPD }}\right)
$$

Where:

$\mathrm{DAC}_{\mathrm{PT}}=$ Discretionary accruals in the test period.

TAC $\mathrm{PT}=$ Total accruals in the test period.

SalesPT = Sales during the test period.

TACPD = Total accruals in the base period.

SalesPD = Sales during the base period.

An indication that earnings management has occurred is shown by a positive DAC coefficient, conversely if the DAC coefficient is negative it means there is no indication that management has made efforts to increase profits through income-increasing discretionary accruals.

\section{EMPIRICAL RESULT AND ANALYSIS}

\section{Descriptive Statistics}

This descriptive analysis is used to provide a description or descriptive of the data seen from the maximum value, minimum value, mean value, and standard deviation values generated from the research variables. The following are descriptive statistical test results:

Siti Chanifah, Hamdani, and Mutiara Wiedyaningtias. Earning management practices in Islamic banking in Indonesia 
Table 1.

Descriptive Statistics

\begin{tabular}{|l|r|r|r|r|r|}
\hline & $\mathrm{N}$ & \multicolumn{1}{|c|}{ Minimum } & Maximum & \multicolumn{1}{c|}{ Mean } & \multicolumn{1}{c|}{ Std. Deviation } \\
\hline DAC2012 & 11 & -1.02 & 1.68 & -0.063 & 0.78332 \\
\hline DAC2013 & 11 & -1.18 & 1.24 & 0.1022 & 0.68106 \\
\hline DAC2014 & 11 & -1.89 & 2.11 & -0.0179 & 1.2128 \\
\hline DAC2015 & 11 & -1.55 & 1.87 & 0.2069 & 0.87636 \\
\hline DAC2016 & 11 & -1.12 & 0.8 & 0.1607 & 0.52174 \\
\hline Valid N (listwise) & 11 & & & & \\
\hline
\end{tabular}

Source: SPSS Output 20

In Table 1, it can be seen that from the 11 Sharia Banks that were sampled in this study showed a minimum value of Earnings Management (ML) in 2012 of -1.02 , while the maximum value in 2012 was 1.68, an average of $-0,0630$ and the standard deviation is 0.78332. In 2013 showed a minimum value of Earnings Management (ML) of -1.18 and a maximum value of 1.24 , an average of 0.1022 and a standard deviation of 0.68106 . In 2014, it showed a minimum value of Earnings Management (ML) of -1.89 and a maximum value of 2.11, an average of -0.0179 and a standard deviation of 1.21280. In 2015 showed a minimum value of Earnings Management (ML) of -1.55 , a maximum value of 1.87 , an average of 0.2069 and a standard deviation of 0.87636 . Whereas in the last year 2016 showed a minimum value of Earnings Management (ML) of -1.12 , the maximum value was 0.80 , the average value was 0.1607 and the standard deviation was 0.52174 .

The DAC data above shows that the earnings management behavior of the sample companies is low because the discretionary accruals of the sample companies are still around 0 (zero). Discretionary accrual values above 0 indicate that the earnings management method is done by increasing earnings. While the value of discretionary accruals which are below 0 or negative value indicates that the method of earnings management carried out by the company is to reduce profits (Fatmawati and Sabeni, 2012: 6). While the mean value of the DAC itself shows that Islamic banks tend to do earnings management by increasing profits, this study is the same as that done by Gumanti (2001).

\section{Earning Management Practices in Islamic Banking in 2012-2016}

In this study, based on sales data, net income, and cash flow statements of operating activities of 11 Islamic banks that are used as a sample of companies for 5 years of the observation period in the financial statements, then discretionary accruals are calculated for each of the Islamic banks that are sampled, then averaged. Discretionary accruals calculation is intended to detect earnings management practices in Islamic banking. Indications of earnings management practices are indicated by positive discretionary accruals, on the contrary, if negative discretionary accruals mean that there is no indication that management has made efforts to increase profits through income-increasing discretionary accruals. This study uses a discretionary accruals approach to measure the existence of earnings management practices in Islamic banking financial statements.

Discretionary Accruals (DAC) of 11 Islamic banks in Indonesia during the 5 years of averaged observations can be seen in the table below:

Siti Chanifah, Hamdani, and Mutiara Wiedyaningtias. Earning management practices in Islamic banking in Indonesia 
The Accounting Journal of BINANIAGA Vol. 05, No. 01, June 2020

p-ISSN: 2527-4309, e-ISSN: 2580-1481

$5^{\text {th }}$ Accreditation Rating: January 14, 2019 - January 13, 2024

Table 2.

Discretionary Accruals (DAC) of Sharia Bank listed on the IDX

\begin{tabular}{|l|c|c|c|c|c|}
\hline \multirow{2}{*}{ Bank } & \multicolumn{5}{|c|}{ DAC } \\
\cline { 2 - 6 } & $\mathbf{2 0 1 2}$ & $\mathbf{2 0 1 3}$ & $\mathbf{2 0 1 4}$ & $\mathbf{2 0 1 5}$ & $\mathbf{2 0 1 6}$ \\
\hline BCA & -0.3171 & 0.2618 & -1.8903 & 1.8706 & -1.1233 \\
\hline BNI & -0.3907 & 0.3413 & 0.0732 & 0.1711 & 0.0584 \\
\hline BRI & 0.0153 & 0.2617 & -0.5277 & -0.3673 & 0.7951 \\
\hline BUKOPIN & -0.2913 & 0.5546 & -1.365 & 0.5486 & 0.7906 \\
\hline MANDIRI & -0.0492 & -0.4426 & 0.2497 & 0.1912 & 0.0745 \\
\hline MUAMALAT & 1.6836 & -0.496 & -0.4246 & 0.4915 & 0.2059 \\
\hline MEGA & -0.25 & 0.2457 & -0.1374 & -0.1807 & 0.3595 \\
\hline MAYBANK & 1.1004 & -1.179 & 1.0545 & -1.5546 & 0.3982 \\
\hline BJB & -1.0209 & -0.426 & 1.5417 & -0.4626 & 0.3181 \\
\hline PANIN & -0.5945 & 0.7636 & 2.1122 & 0.6957 & -0.1975 \\
\hline VICTORIA & -0.5791 & 1.2391 & -0.8834 & 0.8724 & 0.0883 \\
\hline
\end{tabular}

Source: SPSS Output 20

Positive DAC shows that Islamic banks perform earnings management practices in financial statements by increasing earnings, while negative DACs indicate that earnings management practices in Islamic banking are carried out by lowering earnings (Friedlan, 1994). In agency theory, there is an interest between management and owners of business activities in which agents and principals act rationally to maximize their interests (Scoot, 2000). Earnings management practices by minimizing income (income minimization) are done when the company gets high profitability with the aim of not getting political attention. The policy taken is usually in the form of exemption from advertising, research, and development. Management motivation to manage earnings by maximizing earnings (income maximization), nothing else to get a bigger bonus. Likewise, companies that commit a breach of short-term debt contracts, company managers tend to maximize profits. Another form of earnings management is done by income smoothing. The practice is to increase and decrease earnings to reduce reported earnings fluctuations, so the company looks stable and not at high risk (Rokhlinasari S, 2013). Earnings management practices from 2012 to 2016 are as follows:

1. Profit Management Practices in 2012

The results of DAC calculations on Islamic banks in 2012 had negative values on 8 Islamic banks and 3 of them were positive, namely: BCA (-0.3171), BNI (-0.3907), BUKOPIN (-0.2913), MANDIRI (0.0492), MEGA (-0.2500), BJB (-1.0209), PANIN ($0.5945)$, VICTORIA (0.5791). While the DAC is positive, namely: BRI $(0.0153)$, MUAMALAT (1.6836), and MAYBANK (1.1004).

The tendency of Islamic banks' policies in carrying out earnings management practices by lowering profits on their financial statements. In 2012 Bank Indonesia established 5 (five) policies whereby the direction of the policy takes into account macroeconomic management, which must deal with global risks and complex domestic problems (ekonomi.kompas.com, 2011). It can be seen that the government is making efforts to improve stability in the financial sector, as well as maintaining a Bl rate that is consistent with efforts to optimize stimulus to the economy so that it can have an impact on the financial statements of Islamic banks. The increase in profits in Islamic banks may trigger some banks in their policies to conduct earnings management in the form

Siti Chanifah, Hamdani, and Mutiara Wiedyaningtias. Earning management practices in Islamic banking in Indonesia

Page : 14 
of lowering, this motivation is triggered so that banks do not receive political attention (Rokhlinasari S., 2013).

2. Profit Management Practices in 2013

DAC at 11 Islamic banks in 2013, the average bank tends to do earnings management in the form of increasing profits on its financial statements. From 11 Islamic banks, there are 4 Islamic banks that have negative DAC values such as MANDIRI (-0.44426), MUAMALAT (-0.4960), MANYBANK (-1.1790), and BJB ($0.4620)$. While 7 other Islamic banks have positive DAC values, namely: BCA (0.2618), BNI (0.3413), BRI (0.2617), BUKOPIN (0.5546), MEGA (0.2457), PANIN (0.7636), VICTORIA (1.2391).

The impact of the policy in 2012 still had an effect on the financial statements of Islamic banks in 2013, which after minimizing profits for the interests of companies in political circles, various pressures faced in 2013 also influenced the policy decisions of various banks in an effort to improve the stability of their companies in the sector. financial services. Citing the statement of Bank Indonesia that there are various things that are sentiment, the first is the economic shocks that occur in the global financial market. Uncertainty in global financial markets increased in line with negative sentiment towards the plan to reduce monetary stimulus, aka tapering off in the US.

While the global economic downturn finally led to a second shock. The second shock is the pressure on the 2013 balance of payments, the current account deficit is estimated to reach $35 \%$ of the Gross Domestic Product (GDP). Also higher than the deficit in 2012 of $2.8 \%$, the surplus on the side of capital and financial transactions also declined (www.bi.go.id). From this data, it can be interpreted that Islamic banks could have raised profits in their financial statements to get the public's attention so that investors would return to trust in the financial stability of Islamic banks at that time. So that such policies are needed by managers in a company to grow the value of the company to investors in an effort to observe the development of corporate value.

3. Profit Management Practices in 2014

DAC in 2014 showed a balanced positive and negative value. There are 6 Islamic banks that shift earnings management practices by lowering profits in the financial statements, namely: BCA (-1.8903), BRI (-0.5277), BUKOPIN (-1.365), MUAMALAT ($0.4246)$, MEGA (-0.1374), and VICTORIA (-0.8834). While 5 other banks collect money by obtaining profits, namely: BNI (0.0732), MANDIRI (0.2497), MAYBANK (1.0545), BJB (1.5417), and PANIN (2.1122). Astri and Ari (2013), said that Islamic banks practice earnings management by raising and raising profits.

The motivation of Islamic banks in managing earnings is by raising profits, because it is related to government policy in controlling its achievement, namely improving banking security and maintaining the country's economic consistency. While earnings management is done by lowering profits when the bank must ask for consistency in the financial value to be made in the financial statements to be published, so to get profit for the owner of the company must be based on policies in which one of them by generating profits.

\section{Profit Management Practices in 2015}

Positive DACs for 2015 are 7 Islamic banks, namely: BCA (1.8706), BNI (0.1711), BUKOPIN (0.5486), MANDIRI (0.1912), MUAMALAT (0.4915), PANIN (0.6957) and VICTORIA (0.8724). This condition is related to poor finance during 2015, Islamic banks in managing earnings can be triggered by sentiment over, Islamic banks in an effort to increase investors or the public towards Islamic bank finance. Meanwhile, Islamic banks with negative DACs were 4 banks, namely: BRI (-0.3673), MEGA (-0.1807), MAYBANK $(-1.5546)$, and BJB (-0.4626). This condition was canceled by (Sulistyanto and Wibisono, 2003), which stated that Islamic banks conduct earnings management by

Siti Chanifah, Hamdani, and Mutiara Wiedyaningtias. Earning management practices in Islamic banking in Indonesia 
lowering profits. Research on corporate governance has found earnings management practices (Income Returns) for engineering, as indicated by a negative DAC value.

5. Profit Management Practices in 2016

The negative DAC value in 2016 was 2 Islamic banks, namely: BCA (-1.1233), and PANIN (-0.1975). While 9 positive banks are BNI (0.0584), BRI (0.7951), BUKOPIN (0.7906), MANDIRI (0.0745), MUAMALAT (0.2059), MEGA (0.3595), MAYBANK (0.3982), BJB (0.3181), and VICTORIA (0.0883).

In the 2015 period, the bad credit trend continued into 2016, the decline in profits was triggered indirectly by the swelling of non-performing loans (NPLs). The increase in NPL occurred in almost all sectors of the economy, many factors were behind the Indonesian economy, which was caused by external factors, namely: the European and Japanese economies were still in decline, and the recovery of the United States economy had not improved (economy.kompas.com, 2016).

Earnings management practices carried out by Islamic banks in 2016 are required using a pattern that is acceptable to earnings. Almost all Islamic banks with positive DAC values, while 2 Islamic banks have negative values. According to Wahyuningsih (2007), doing positive discretionary accruals means the company maximizes revenue. Successful management earnings occur through management by increasing profits. If the discretion is negative, it means the company is minimizing revenue. Generate management profits made by management by lowering profits.

\section{CONCLUSIONS}

Based on tests that have been carried out during the observation period, the research results can be concluded that Islamic banking practices earnings management in its financial statements. Evidenced by the value of discretionary accruals for 5 years is positive and negative. Where a positive value can be interpreted that Islamic banks practice earnings management by increasing profits, while negative values are done by lowering profits.

Aryaccruals discretion value in 11 Islamic banks is still below the number 0 (zero). This means that Islamic banks practice earnings management by lowering profits. Of the 11 Islamic banks studied, 18 earnings reports had positive-value discretionary accruals. Whereas 16 earnings reports with discretionary accruals value were negative from 2012 to 2016.

In 2012, Islamic banks tended to practice earnings management by lowering profits, whereas in 2013 Islamic banks tended to do earnings management by raising profits. In 2014, several Islamic banks detected earnings management practices by increasing profits and decreasing profits as in the DAC report which tends to have positive and negative values, while in 2015 and 2016 Islamic banks detected earnings management practices by increasing earnings.

\section{REFERENCES}

Anthony, R. N., and Govindarajan, V. (1995). Management Control System. Eight Editional International Student Edition. Richard D. Irwin Inc. U.S.A.

Bank Indonesia. (2018). Data Bank Syariah di Indonesia. www.bi.go.id.

Bank BCA Syariah. Laporan Keuangan Bank 2012 - 2016. www.bcasyariah.co.id.

Bank BNI Syariah. Laporan Keuangan Bank 2012 - 2016. www.bnisyariah.co.id.

Siti Chanifah, Hamdani, and Mutiara Wiedyaningtias. Earning management practices in Islamic banking in Indonesia

Page : 16 
The Accounting Journal of BINANIAGA Vol. 05, No. 01, June 2020

p-ISSN: 2527-4309, e-ISSN: 2580-1481

$5^{\text {th }}$ Accreditation Rating: January 14, 2019 - January 13, 2024

Bank BRI Syariah. Laporan Keuangan Bank 2012 - 2016. www.brisyariah.co.id.

Bank Bukopin Syariah. Laporan Keuangan Bank 2012-2016. www.syariahbukopin.co.id.

Bank Syariah Mandiri. Laporan Keuangan Bank 2012-2016. www.syariahmandiri.co.id.

Bank Muamalat Syariah. Laporan Keuangan Bank 2012-2016. www.bankmuamalat.co.id

Bank Mega Syariah. Laporan Keuangan Bank 2012-2016. www.megasyariah.co.id

Bank Jabar dan Banten Syariah. Laporan Keuangan Bank 2012-2016. www.bjbsyariah.co.id

Bank Panin Syariah. Laporan Keuangan Bank 2012-2016. www.paninbanksyariah.co.id

Bank Syariah Bukopin. Laporan Keuangan Bank 2012-2016. www.syariahbukopin.co.id

Bank Victoria Syariah. Laporan Keuangan Bank 2012-2016. www.bankvictoriasyariah.co.id

Bursa Efek Indonesia. www.idx.co.id

Faradila, A., and Ari, D. C. (2013). Analisis Manajemen Laba pada Perbankan Syariah. JRAK, Vol 4 (1): 57-74.

Friedlan, M. L. (1994). Accounting Choice of Issues of Initial Public Offerings. Contemporary Accounting Research, 13: 1-36.

Nurfakihiswara, I. (2017). Good Financial Performance, Category Islamic Bank. Taken from: www.wartaekonomi.co.id. (29 November 2017).

Jones, J. J. (1991). Earning Management During Import Relief Investigations. Journal of Accounting Research, Vol. 29 (2): 193-228.

Lestari, N. M. (2015). Sistem Pembiayaan Bank Syariah (Berdasarkan UU No. 21 Tahun 2008). Jakarta: Grafindo Books Media.

Novius, A. (2011). Earning Management dalam Penawaran Saham Perdana Perusahaan Manufaktur di Bursa Efek Indonesia. Jurnal IImu Manajemen dan Akuntansi Terapan, Vol. 2 (2).

Padmantyo, S. (2010). Analisis Manajemen Laba pada Laporan Keuangan Perbankan Syariah (Studi pada Bank Syariah Mandiri dan Bank Muamalat Indonesia). Jurnal Manajemen dan Bisnis, Vol.14 (2): 53-65.

Rahayu, A. (2009). Paper Deskriptif Model Jones (1991). Tanpa Nama Tempat.

Runturambi, I. V., et al. (2017). Jurnal Riset Akuntansi Going Concern, Vol.12 (2): 857-873.

Siti Chanifah, Hamdani, and Mutiara Wiedyaningtias. Earning management practices in Islamic banking in Indonesia 
The Accounting Journal of BINANIAGA Vol. 05, No. 01, June 2020

p-ISSN: 2527-4309, e-ISSN: 2580-1481

$5^{\text {th }}$ Accreditation Rating: January 14, 2019 - January 13, 2024

This page intentionally be emptied.

Siti Chanifah, Hamdani, and Mutiara Wiedyaningtias. Earning management practices in Islamic banking in Indonesia

Page : 18 